\title{
The Correlation between Median Rhomboid Glossitis and Fungal Infection: A Review Article
}

\author{
Nanda Rachmad Putra Gofur ${ }^{1 *}$, Aisyah Rachmadani Putri Gofur ${ }^{2}$, Soesilaningtyas ${ }^{3}$, Rizki Nur \\ Rachman Putra Gofur ${ }^{4}$, Mega Kahdina ${ }^{4}$ and Hernalia Martadila Putri ${ }^{4}$
}

${ }^{1}$ Department of Health, Faculty of Vocational Studies, Universitas Airlangga, Surabaya, Indonesia

${ }^{2}$ Faculty of Dental Medicine, Universitas Airlangga, Surabaya, Indonesia

${ }^{3}$ Department of Dental Nursing, Poltekkes Kemenkes, Surabaya, Indonesia

${ }^{4}$ Faculty of Medicine, Universitas Airlangga, Surabaya, Indonesia

*Corresponding author: Nanda Rachmad Putra Gofur, Department of Health, Faculty of Vocational Studies, Universitas Airlangga,

Surabaya, Indonesia

\section{ARTICLE INFO}

Received: 幽 December 14, 2020

Published: 幽 December 21, 2020

Citation: Nanda Rachmad Putra Gofur, Aisyah Rachmadani Putri Gofur, Soesilaningtyas, Rizki Nur Rachman Putra Gofur, Mega Kahdina, Hernalia Martadila Putri. The Correlation between Median Rhomboid Glossitis and Fungal Infection: A Review Article. Biomed J Sci \& Tech Res 32(4)-2020. BJSTR. MS.ID.005288.

Keywords: MRG; Fungal Infection; Immunocompromised

\section{ABSTRACT}

Background: Median rhomboid glossitis (MRG) is the condition with the central papillary atrophy of the tongue, and it affects $1 \%$ of the population. Rogers and Bruce stated that men are affected 3 times more often than women.

Objectives: To know the correlation between median rhomboid glossitis and fungal infection. Problem Statements: Median rhomboid glossitis often occurs in people with diabetes mellitus or others immunocompromised condition. This condition also can lead the fungal infection in oral cavity.

Discussion: In people who is smoker can increase the candidal carrier rate in both diabetic and healthy subjects. Diabetic patients with oral candidiasis who were smokers had significantly higher candidal load than diabetic patients with oral candidiasis who were ex-smokers or who did not smoke. MRG is higher in immunosuppressed patients, diabetics, and in patients on broad-spectrum antibiotics.

Conclusion: There was a highly significant statistical correlation between MRG and Candida species. In particular, the midline of the tongue is suitable for intense overgrowth of Candida organisms.

\section{Introduction}

Median rhomboid glossitis (MRG) is clinical appearance with atrophy of central papillary tongue. This conditions happens within almost $1 \%$ among individual. Study said that men more likely to had this condition compare to women. Moreover, this gender dominant was found due to many predisposition factor. Another study found among 28 MRG patients, 7 patients is women, and the rest is men. MRG is mainly visible in the midline of tongue, could be dorsal or central. Clinical appearance of MRG is commonly symmetric but could be asymmetry, there is loss of papill area arising from anterior to dorsal. Sometimes MRG also appears in the paramedial location. Surface conditions of MRG was smooth. Dominant patients with MRG had no pain or asymptomatic, but some of them migh had persistent pain, and irritation [1]. Median rhomboid glossitis is present in about $1 \%$ of the population and most often affects men between the ages of 30 - 50 years of age. It typically presents as an ovoid area about 2 - 3 centimeters long in its longest dimension (Figure 1).

As most cases of median rhomboid glossitis are without symptoms, it is often first noticed by the dentist during a routine examination. However, some patients may experience a burning sensation when eating certain foods. Median rhomboid glossitis is currently thought to represent a chronic fungal (candidiasis) infection in this area of the tongue [2]. There are several predisposing factors associated with MRG such as smoking, denture wearing, 
diabetes mellitus, as well as candidal infections. Aim of this study is to review association MRG and relationship with predisposition factors, such as aging, dominance of men in prevalent, smoking habits, denture wearer, and systemic conditions especially diabetes mellitus [3].

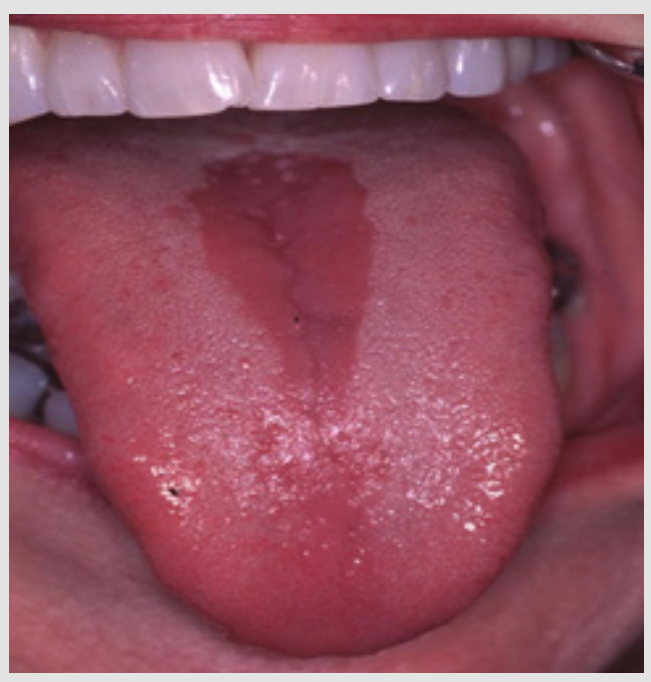

Figure 1: Clinical Appearance in Median Rhomboid Glositis.

\section{Aim of this study}

To know the correlation between median rhomboid glossitis and fungal infection.

\section{Discussion}

\section{Clinical Manifestation}

Median rhomboid glossitis (MRG) is defined as the central papillary atrophy of the tongue and it affects $0.01 \%-1.0 \%$ of the population. MRG is typically located around the midline of the dorsum of the tongue. It occurs as a well-demarcated, symmetric, depapillated area arising anterior to the circumvallate papillae. However, it sometimes appears in the paramedial location. The surface of the lesion can be smooth or lobulated. While most of the cases are asymptomatic, some patients complain of persistent pain, irritation, or pruritus. When MRG is concomitant with a palatal inflammation, which is called the kissing lesion [4].

\section{Prevalence}

Prevalence of MRG in population just in little amount, is $0.9 \%$ to $5.4 \%$. Previous study found that average country in the world had $0.2 \%$ prevalence. But study in Turki said in its country, their population had MRG almost $0.7 \%$ higher than the rest of the world. Moreover, another country reported that 2-3\% among population. Interestingly, gender dominant with MRG prevalence was men, more dominant 3 until 5 times than women. Study also conclude that the prevalence ratio MRG in population was one patient among 12 individual.

\section{Factor Predisposition}

Factor predisposition among MRG patients was plenty. First was smoker, smoker could increase incidence rate, especially with systemic disease. But smoker in health subjects also can increase MRG or candidiasis in oral cavity. Moreover, Patients with systemic disease, especially diabetes, had the highest candida count in oral cavity using fungicidal examination. Also, this condition happens to patients with systemic condition, although the patients was quit smoking years ago. Especially uncontrolled diabetic condition, study found higher candida culture [5]. This condition also found in both diabetic type 2 and 1. 85\% MRG patients smoked tobacco was found in previous study, compared healthy subjects in 40 patients. That study was justification with age or gender in same proportion. Another factor was denture wearers, MRG was significantly high in this condition. Denture weares is local condition just in oral cavity, not systemic one, so this suggest that local factors also had role in MRG condition [6].

Few previous studies also underline that diabetes was main factor in development of MRG. Next factor was smoking tobacco, might had role in development of MRG. Another local factor was dental prosthesis or denture wearers, traumas, and its combination might be predisposition factor to MRG. Also, there is evidence report about denture wearers and MRG. But there is one to notice that individual who using denture wearers commonly elderly. Elderly oral cavity had slight transformation, including oral microbiota, immune aging might play role in development of MRG. However, the exact pathophysiology between MRG and denture wearers still lack information $[7,8]$.

\section{Correlation between Median Rhomboid Glossitis and Fungal Infection}

MRG study could not be separated with Candida study, especially candida albicans. Many study focus that candia albicans species is main etiology of MRG. However, candida albicans is normal flora in oral cavity, but might be change quantity if there is another factors. Previous study also concludes that dysbiosis of candida albicans was first condition in development of MRG, and there is high correlation impact between candida albicans and MRG. There is proof that almost $88 \%$ MRG dominated by candida albicans using culture study [9].

Common places for candida albicans in oral cavity are tongue or glossa, study reported that almost $50 \%$ of the candida population might turn to dysbiosis if there are predisposition factors. Glossa is the valuable oral source for Candida. nevertheless, the mid of the glossa is suited against quick overgrowth of Candida organisms. This chance occurs because impaired bloodline accommodate to the mid-dorsal approach of the glossa might predispose it to the developing of candidiasis and, presumptively, to the resultant loss of filamentous papillae [10]. 
These days, MRG might be identified as an oral disease, that commonly dominated by candida albicans. These diseases related with disease that come forward from Candida infections. However, the pathway mechanism is still be a controversial and needed further study. One that we know, beside candida albicans, there is another predisposition factors had role in MRG. Few predisposing factors has been mentioned before, such as smoking habits, denture wearer, and systemic disease as human immunodeficiency virus, diabetes mellitus and might immune conditions. Another factors are pharmacological treatment in several diseases, the example is use of corticosteroid, steroid and inhalers for autoimmune condition. Moreover, study sill had conclusion that candida albicans is main cause, from culture fungal or using imunohistopathology examination. There is high correlation report using significant statistical relationship of MRG and Candida species. Another proof is oral cavity, especially glossa midline is highly suitable for intense overgrowth of Candida organisms [11].

MRG is frequently a symptomless lesion. besides, whole of the cases before were symptomless. Consequently, they did not demand any treatment; nevertheless, these patients still should keep under observance. Another problem to concern, although MRG was found in HIV patients, not all MRG had HIV. But MRG should be as manifestation of systemic disease such as diabetes. Unlikely kissing lesions on the hard palate that might symptoms in HIV, we should consider that another predisposition factors might be induce this condition, such as smoking habits or local factors as trauma and denture wearers. Moreover, there is no clear association between MRG and cancer, but there was evidence reports of malignant transformation from MRG conditions $[12,13]$.

\section{Conclusion}

There was a specific correlation with strong amount candida albicans in MRG conditions. Common places for MRG are glossa midline that very suitable for intense overgrowth of Candida organisms.

\section{References}

1. Avcu N, Kanli A (2003) The prevalence of tongue lesions in 5150 Turkish dental outpatients. Oral Dis 9: 188-195.

2. Lago-Méndez L, Blanco-Carrión A, Diniz-Freitas M, Gándara- Vila P, García-García A, et al. (2005) Rhomboid glossitis in atypical location: case report and differential diagnosis. Med Oral Patol Oral Cir Bucal 10: 123-127.

3. Carter LC (1990) Median rhomboid glossitis: Review of a puzzling entity. Compendium 11: 448-451.

4. Rogers RS, Bruce AJ (2004) The tongue in clinical diagnosis. J Eur Acad Dermatol Venereol 18: 254-259.

5. Mc Nally MA, Langlais RP (1996) Conditions peculiar to the tongue. Dermatol Clin 14: 257-262.

6. Kanafani ZA, Perfect JR (2008) Antimicrobial resistance: Resistance to antifungal agents: Mechanisms and clinical impact. Clin Infect Dis 46: 120-128.

7. Montero CI, Shea YR, Jones PA, Harrington SM, Tooke NE, et al. (2008) Evaluation of pyrosequencing technology for the identification of clinically relevant non-dematiaceous yeasts and related species. Eur J Clin Microbiol Infect Dis 27: 821-830.

8. Erriu M, Boscarelli F, Peluffo C, Orrù G, Nucaro A, et al. (2010) A rapid sample method for HLA haplotype typization. A preliminary study on celiac patients. Minerva Stomatol 59: 477-487.

9. Rex JH, Pfaller MA (2002) Has antifungal susceptibility testing come of age? Clin Infect Dis 35: 982-989.

10. Germano F, Bramanti E, Arcuri C, Cecchetti F, Cicciù M (2013) Atomic force microscopy of bacteria from periodontal subgingival biofilm: Preliminary study results. Eur J Dent 7: 152-158.

11. Terai H, Shimahara M (2007) Partial atrophic tongue other than median rhomboid glossitis. Clin Exp Dermatol 32: 381-384.

12. Yarom N, Cantony U, Gorsky M (2004) Prevalence of fissured tongue, geographic tongue and median rhomboid glossitis among Israeli adults of different ethnic origins. Dermatology 209: 88-94.

13. Espinoza I, Rojas R, Aranda W, Gamonal J (2003) Prevalence of oral mucosal lesions in elderly people in Santiago, Chile. J Oral Pathol Med 32: 571-575.
ISSN: 2574-1241

DOI: $10.26717 /$ BJSTR.2020.32.005288

Nanda Rachmad Putra Gofur. Biomed J Sci \& Tech Res

(C) This work is licensed under Creative

Submission Link: https://biomedres.us/submit-manuscript.php

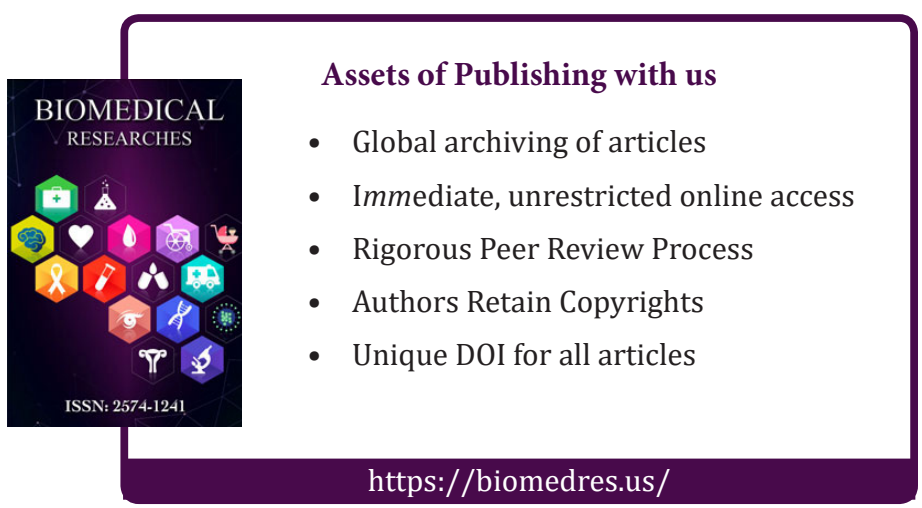

